\begin{tabular}{|ccc|}
\hline Jurnal Penelitian dan Evaluasi Pendidikan \\
Volume 21, No 2, December 2017 (189-205)
\end{tabular}

\title{
DEVELOPING QUALITY EVALUATION INSTRUMENT FOR ISLAMIC SENIOR HIGH SCHOOL
}

\author{
Muh. Shodiq ${ }^{1}$, Suyata ${ }^{2}$, Sutrisna Wibawa ${ }^{2}$ \\ ${ }^{1}$ Institut Islam Mamba'ul ulum Surakarta, ${ }^{2}$ Universitas Negeri Yogyakarta \\ ${ }^{1}$ Jalan Sadewa No.14, Serengan, Kota Surakarta, Jawa Tengah 57155, Indonesia \\ ${ }^{2}$ Jl. Colombo No. 1, Depok, Sleman 55281, Yogyakarta, Indonesia \\ * Corresponding Author. Email: azizbukanabaz@gmail.com
}

\begin{abstract}
This research aims to develop concept of the quality of education in Islamic Senior High School and know the validity and reliability of the factors that affect the development of quality indicators in Islamic Senior High School. Development of the procedures in this research included a needs analysis, product development, product test, and implementation/ dissemination. A sample of this research was Islamic Senior High School 1 Surakarta and Islamic Senior High School 1 Purwodadi, which were determined by a purposive random sampling. Data analysis techniques used was Confirmatory Factor Analysis (CFA), Lisrel version 8.54, and descriptive qualitative analysis. The results of the study showed that the development of quality indicator for Islamic Senior High School includes six criteria namely, the role of school principals, management of Islamic Senior High School, educators and Staffs, Students, facilities and infrastructures and the role of the community. It has met the indicators fit models, the Chi-Square value is 152.07, $\mathrm{p}>0.05$, and RMSEA is 0.068. The advantages of this Islamic Senior High School Quality Evaluation Instrument are namely comprehensive holistic approach, easy, not depending on the specific lessons conducted by educators. It can be used to map the various aspects of the education in Islamic school that need to be repaired; it is open to further developed) Islamic school quality evaluation instrument can be used as a school self-evaluation; it can be used effectively by schools without interrupting the learning process; it supports school accreditation and quality guarantee, and it is also independent.
\end{abstract}

Keywords : the development of the instrument, quality evaluation, Islamic Senior High School

Permalink/DOI: http:/ / dx.doi.org/10.21831/pep.v21i2.15675 


\section{Introduction}

The presence of Islamic education institutions in this country was marked with the entry and development of Islam. The process of Islamisation is strengthened by the institution as the media (Tjandrasasmita, 1984; Daulay, 2007, pp. 14-15). The development of Islamic education institutions, marked by the emergence of various educational institutions gradually, was started from Sumatera to the island of Java that continued the development of Islamic education that had been done in the land of Minang (Jonah, 1996, p. 63).

The development of educational institutions has been studied to inform about the growth and development. This is in line with the principle generally held by the community of Indonesian Islam, namely to maintain the good tradition of the past and to take a new better tradition (Nizar, 2011, p. 280).

Since the emergence of the Islamic School until this time, the growth and development of Islamic School can be grouped into three categories. First, mapping based on the history of the growth; second, based on the position of Islamic School in the national education system and third is the effort of the government (Religion Ministry) to promote and improve the quality of Islamic School to meet the global competition (Widdah, Suryana, \& Musyaddad, 2012 , p. 15). The Islamic School was intended to create powerful religious professionals, and to prepare generations that are ready to develop Islamic School (Maksum, 1999, p. 131).

Islamic education in Indonesia had been running for long and had a long history, but on the other hand, Islamic education was still eliminated from the National Education System. This situation didn't last until the issuance of a joint decree of $3 \mathrm{Mi}$ nisters of Religion, Education and Culture and minister of Internal Affairs March 24th, 1975; at that time, the Minister of Religious Affairs was headed by Mukti Ali attempting to restore our outdated Islamic education to enter the mainstream of national education
(Tilaar, 2000, p. 147). The purpose of the decree is to improve the quality of education in the institutions of Islamic education especially for the field of non-religion subjects to have balance between the characteristic of Islamic education and the quality of education in accordance with the demands of the ages (Shaleh, 2004, p.114).

It is undeniable that the effects of this equation have increased the burden of Islamic School. Islamic School in one side must improve the quality of education that is generally equal to the applicable standards in public schools. In line with Arif Rahman, Tilaar (1999, pp. 30-51) also mentions some criteria for its problem of education including Islamic School in Indonesia namely the low quality of teachers, teachers teaching not in accordance with his background, low input low, less sufficient facilities and infrastructure, curriculum which is not relevant to the needs and the heavy burden in the process of teaching and learning which is the students for the curriculum, not a curriculum for the students, and the target seems too much to achieve.

Ahid (2009, p. 26) in the research titled "Its Problem Islamic Senior High School in Indonesia" mentioned that there are three background problems of Islamic Senior High School students in Indonesia namely; (a) education background - many students are from public schools; (b) low input; and (c) students with no background of pesantren. The three problems result in the students problematic in learning religion that causes the low mastering of religious education.

The issuance of three Ministers joint decree indicates that the existence of the Islamic School is strong enough to go equally hand in hand with the public schools and it is considered as a positive step for the improvement of the quality of Islamic School especially in the level status, value and its curriculum (Fadjar, 1998).

Public perception of Islamic School in this modern era is no longer as a second class school. They have become the first choice in the big cities in this country. 
Until this time, there have not been any references made as the measurement of the quality assessment of the Islamic School as the public schools have. Research Results Doyle as quoted by Kyle (1985), stated that one of the indicators of the success or effectiveness of the school is the quality of the students learning achievement.

Moh Ali in Module $5 \mathrm{~KB} 2 \mathrm{PGSD}$ UT.2007 formulates indicators of schools quality oriented in quality of the graduates, giving good services, professional teachers, the availability of adequate learning facilities and the management of education funding and empowerment of School Based Management to be more optimal. The concept of the quality requires education providers understand and realize that the product is not school but goods or services education services. Students should receive balanced service to make them quality graduates in the future.

Efforts to ensure a quality education services is the way to go in the process of the evaluation of the whole aspect of education that graduates are produced in accordance with the standard of education as assigned. Related to the implementation of a quality education according to the national education standard, the government must provide services openly to the stakeholders. One of the roles of government related to the quality of education is the BAN S/M or the National Accreditation School/Islamic School which is one part of the guarantee system for the quality as mandated by the Law on National Education System. Any issues related to the implementation of the BAN S/M accreditation doesn't reflect the feasibility of education program in accordance with the national education standard (Subijanto \& Wiratno, 2012, p. 311).

The Ministry of religion states that there will be some efforts done by government to improve the Islamic Senior High School quality in education which some of them are still considered low. There is around 91\% Islamic Senior High School in Indonesia managed by the private sector with low quality. They are not able to com- pete with the other Public High schools because of the facilities and supporting resources that are not sufficient (www.kemenag.go.id, 2008). Data from the National Accreditation, in 2013, in 13 Indonesian provinces of the west part of Indonesia show that 161 Islamic Senior High School are not accredited (5.62\%) and 578 $(20.17 \%)$ have not yet been accredited. This means that the quality of Islamic Senior High School in general has not been able to reach an ideal position. Various obstacles that became the problem of the quality of Islamic Senior High School namely teachers have not yet been able to meet the qualifications and competencies in accordance with the requirements of the education evenly, the low quality of the learning process, limited managerial capabilities of the Islamic School head and support from stakeholders that have not yet been maximum (www.republika.co.id, 2015).

The Department of Education (2002, p. 12) stated that the school quality inclusively contains elements of an effective school which is based on the process input and output. This means that the indicators of the quality of schools are a reference to develop the details of the quality assessment. These indicators are elaborated from many aspects that become the focus of the assessment and they are developed from the dimensions of the quality based on the construct of the school quality.

According to the Juran M. N (Nasution, 2001, p. 22), the quality of a product is the suitability of the use of the products (finess for use) to meet the needs and customer satisfaction. Crosby (Nasution, 2001, p. 26) stated that the quality is conformance to requirement, which is in accordance with the required quality standard or the standardized quality. A product has quality when it is in accordance with the quality standards that have been determined.

Sumayang (2003, p. 322) stated quality is a level where the design of a product specification of goods and services in accordance with the function and its use. Understanding the quality or quality can be re- 
viewed from two perspectives the concept. The first concept about the quality is absolute and the second concept is relative (Sallis, 1993, p. 58). In the concept of the absolute quality it shows to the nature of that describes the degree of "good" at goods or services produced or supplied by a certain institution. The opposite concept of the absolute is the concept of the relative quality. The degree of the quality depends on the assessment of the customer that takes advantage of goods or services. Based on the above understanding it can be interpreted that the quality of a match between the products produced by the institution with the requirements that the customers want to give satisfaction to the customer.

A dynamic view sees quality schools as a school that has the ability to develop the potential of the foundation of the students and the educators up to the fullest, as measured on the impact of the school in the form of added value on both the development of knowledge and the things that are more personal (Aspin, Chapman \& Wilkinson, 1994, pp. 3-5). Ariani (2004, p. 8), summarizes the definition of the quality proposed by the various experts that the quality is basically " ... the entire characteristic or characteristics of products or services in the aim to meet the needs and customer expectations".

Characteristics of the quality of education services according to Zeithaml \& Bitner (2002, pp. 12-14) there are ten factor determinant in the achievement of quality, namely: (1) reliability; (2) interdependency; (3) competencies; (4) access; (5) ethics (and politeness); (6) communications; (7) credibility; (8) security; (9) understand the needs of customers; and (10) tangibles. From the explanation above it can be understood that the concept of the quality requires education providers to understand and realize that the product is not school but goods or services education services. Students should be balanced so that the service quality graduates.

As a quality expert, Sallis (2002, pp. 151-159) assigns quality indicator as an instrument of self-evaluation. Quality indica- tor as developed by Sallis provides data about the contribution of each indicator to the improvement of the quality of such as: (1) effective learning and teaching, (2) leadership, (3) staff, (4) students, (5) standards, (6) organization, (7) physical environment and resources, (8) external relations, (9) access, and (10) service to special event. The concept of the indicators of School Quality that developed by Taylor, West, \& Smith from Utah State University in 2006 has seven indicators to assess the quality. The seven quality indicators are: (1) parent support, (2) teacher excellence, (3) student commitment, (4) school leadership, (5) instructional quality, (6) resource management, and (7) school safety

The measurement of the quality of the school can be done by many parties, starting from the school committee to the stakeholders. In this model the measurement of the quality of schools is done by the school community, mainly by the students, teachers, principals, parents and the school committee that will be very useful as a positive step to accelerate the school performance.

To specify the quality of the school, it can be done through various approaches. Some approaches to specify the quality of schools are school accreditation, certification and the national examination (Government Regulation of the Republic Indonesia No 19 year 2005 on National Education Standards). A measurement of the school quality must be designed in the form of evaluation instruments such as the accreditation of schools through school self-evaluation instrument, certification through the feasibility evaluation instrument for teachers in the form of a portfolio, national examination in the form of an instrument of evaluation for the national examination.

Based on observation and information in the field there are various problems in the quality of education in Islamic Senior High School that need further development of quality indicator, which includes: (1) the role of the Islamic School Head (2) management of Islamic School, (3) teachers and educational supports, (4) Students, (5) facili- 
ties and infrastructure, and 6) the role of the Community. The six factors are elaborated upon as the indicators of quality in Islamic School.

The management, as one of the components of the quality evaluated, has some indicators such as (1) planning, (2) organizing, (3) guidance activities, (4) conditioning, and (5) controlling. Cheng \& Ming (1997, pp. 22-31) shows that (1) to assess the quality of schools, some indicators to develop may be different to provide information about the performance of the education institution in the aspects of input, process and output; (2) the difference in selecting and emphasizing the indicators reflect a hope and a different interest related to management strategies to achieve particular quality of school in a particular environment; (3) constituted by a different concept about the quality of different schools, people can use different indicators to assess the quality of schools and strategy and these indicators may not include all aspects regarding inputs, process and the output of an education institution.

In the field of education management quality or school based management quality is a new alternative in the management of education which emphasizes to the independence and creativity in schools. This concept was introduced by the theory of effective school which focuses more on the improvement of the education process (Edmonds, 1979, p. 9). Several indicators that show the character of this management concept among others as follows: (1) school environment that is safe and orderly, (2) schools have mission and quality targets to be achieved, (3) schools have strong leadership, (4) the high expectations of the school personnel (principals, teachers and school staffs including students) to achievement, (5) The development of the school staffs according to the demands of science and technology, (6) the existence of evaluation practitioners who continuously evaluate various aspects of the academic and administrative, and the utilization of the results for the enhancements/improvement of the quality and (7) communication and intensive support from parents/community (Umaedi, 1999, p.4).

The process of a quality education is a form of quality support from various aspects of education such as clear objectives learning resources, teacher professional education, adequate equipment and infrastructure, facilities, media and the environment that supports. Education quality indicator according to the Mahdi (2016, p. 11) is the achievement of the eight standards in the national education standard, namely: graduate competency standard, Content Standard, Educators and staffs, standard of process, standard of facilities and infrastructure, financing, management standards and education evaluation standards. The eight standards are applied to achieve a quality Islamic School education. According to Widdah (2013, p. 78) indicators considered for the success of the Islamic School are the context, inputs (input), process the results (output) and the impact of (outcome).

The result of monitoring and evaluation is information that can be used to make a decision to support the implementation of the program to improve the quality of Islamic School successfully as expected. Based on observation and information in the field, there are six elements that affect the quality of Islamic Senior High School: (a) the role of school principals, (b) The Management of Islamic School, (c) Educators and Staffs, (d) Students, (e) equipment and infrastructure, (f) The Role of the community. The tasks and the role of the school head according to Glickman, Stephen, and Jovita (Glatthorn, 2006, p.232) is related to the teachers that help develop teachers' competencies. There are four ways to help teachers' competencies; offering aid directly, providing education service, working with teachers in developing the curriculum and assisting teachers in doing classroom action research.

Komariah $(2005$, p. 57$)$ shows that the effectiveness of the schools affects positively and significantly the school culture as representations of the visionary leadership that is quality oriented. Leadership quality 
as one of the components contributes to establish the quality of the school (Sallis, 2002 , p. 150). He outlines the components of leadership in five parts namely; leadership of learning, leadership of the organization, leadership of moral, leadership of managerial and leadership of role model.

Based on the policy of National Education (Depdiknas, 2006), there are seven roles of the school principal namely as educator, administrator, manager, supervisor, leader, the creator of the work climate and entrepreneurs. The impact of the task and role of the school principal must be understood to see his performance in understanding and comprehending the minimum standard of services (MSS).

Law No. 20/2008 on National Education System states that every citizen is entitled to a quality education services. So the Indonesian government issued the Minister of National Education Law No. 16 year 2007 about Standard of academic qualification and competence of the teachers. There are four main models to improve the quality of teacher competencies in schools; first, improvement through education and training (off the job training), second, training in the implementation of tasks or on the job training. This model is known as internships for new teachers by following the senior teachers who are considered good to learn from. Third, as done in Japan it is a lesson study. This activity on the principle is a collaborative teaching to improve the teacher performance in the classroom by focusing on teacher's positive impacts on the students learning activities. Fourth, it is an improvement through research activities of classroom action research (CAR/PKT).

Suhardjono (1990, p.93) finds that the differences in the students characteristics and in organizing learning materials affect the acquisition and retention of learning. Meanwhile, Paulina Pannen (Padmo, 2003, p. 221) asserts that in designing and implementing, if the materials are associated with the characteristics of the students culture, the results of student learning will respectively increase.
Student characteristics are all aspects or the quality of an individual that has been possessed. Analyzing the student is intended to find out the characteristics of every individual student. Reigeluth (1983, p. 72), as a scientist of learning, puts the student characteristics into one of the most influential variable in the development of learning management strategy.

The facility owned by the quality school is a complete/adequate equipment and infrastructure to support a good learning process including providing learning experiences for students. In the law of Republic Indonesia No. 20 Year 2003 Ch. XII Article 45, it is mentioned that each unit of formal education and informal provide facilities and infrastructure that meet the needs of education in accordance with the growth and development of the potential of physical, intellectual, social emotional and psychological of the Students.

In order to support the effectiveness of learning optimization by the school to perform maintenance and utilization of school facilities effectively and efficiently, technically, its mechanism is regulated by each laboratory coordinator or the coordinator of the unit while the school will do the monitoring and evaluation on effective utilization of the school facilities. So the management of the facility should be done by the school, starting from the procurement, maintenance and repair, as well as development. This is one of the forms of the most visible quality culture on the empowerment of the school facilities that make the students feeling comfortable, enjoyable, easy to find the learning sources and easy to do their assignments.

The education program which is effective and efficient is able to create a balance between the supplies and demands of the learning sources and able to achieve the goals without any serious obstacles. Effective is the achievement of objectives as have been specified. Effective school is a school that all of its components are achieved optimally, not only on the student 
performance but also on the performance of the school (Rahman, 2012, p. 235).

Community and the school improved quality are two things that could not be separated since community participation exists in the SBM as one element to improve the quality of the school/education. Unfortunately the role of the community especially parents in education is still very small. Community participation in general is limited to donating funds, while other support such as thought, moral and goods/services are less noted. In order to let the community participate in education is, one of them, by doing reorienting educational implementation by involving the role of the community through the improvement of school quality in a school-based management.

In this research, the quality measurement used is a quality evaluation instrument developed based on the implementation of education in the school which is formative for the improvement of the school quality and it can be done by the school community. A measurement of the schools developed has validity, reliability and feasibility to use.

The purpose of this research is to develop an instrument of quality evaluation for Islamic Senior High School that can provide information about the role of school principals, Islamic School management, educators and staffs, the role of the community, Students, facilities and infrastructure that can be useful to optimize the education implementation.

The benefits of this research for the program organizer, stakeholders of the quality development of Islamic Senior High School are as a consideration to develop and optimize comprehensive implementation of the program of a kind. For the managers of Islamic Senior High School it is expected to be made as a material to develop the staffs. For the facilitators, it can become the materials for self introspection. For the ministry of religion, it can be used as consideration in doing coordination and collaboration in the effort to improve the quality of the service of the Islamic Senior High School.
It is theoretically enriching the study or strengthening the theory that already exists.

\section{Method}

The research was conducted in MAN 1 Surakarta and MAN 1 Purwodadi. Procedure development in this research refers to the procedures that have been put forward by Borg \& Gall (1983), which includes a need analysis, product development, product test, and implementation/dissemination. Samples of this research were MAN 1 Surakarta and MAN 1 Purwodadi, which were determined by purposive random sampling.

The subject of the trial in the research and development follows the studies of Borg \& Gall (1983, p. 775), which was done in three stages. The first phase is referred to as preliminary testing field applied on 20 students, 15 teachers, 5 educators, and 5 parents. The second stage was referred to as the main field testing, applied on 50 students, 30 teachers, 10 educators, and $10 \mathrm{pa-}$ rents, and the third phase was referred to as the operational field testing, applied on 320 students, 70 educators, 20 educators, and 20 parents.

The data collection instruments used was questionnaire, observation sheet and guided interview. Data analysis techniques used was: (a) Confirmatory Factor Analysis (CFA), (b) Lisrel version 8.54, and (c) descriptive qualitative analysis. Quality indicator development through conceptual studies, theoretical and empirically, are proved in the field through observation, interview, validation documentation/expert judgment, reliability tests and validation instrument details.

Techniques and data collection in this research used inventories attitudes, observation/observation, focus group discussion (FGD), questionnaires and interview.

Data analysis technique used was descriptive analysis to explain the factual quality indicator characteristics of Islamic School that were used during the research, in addition to explain the characteristics of a Islamic School quality indicator development

Developing Quality Evaluation Instrument for Islamic ... - 195 Muh. Shodiq, Suyata, Sutrisna Wibawa 
results were based on the theory of measurement. Descriptive analysis was also used to explain the indicators which was a reflection of the variables measured and the aspects that can determine the validity of the evaluation instruments used to evaluate the quality of Islamic School.

\section{Research Results and Discussion}

The Results of the Initial Product Development

The results of the initial product development in the form of Islamic Senior High School - quality evaluation instrument that consists of three initial components; there are the role of school principals, the management of schools and educators and staffs. Those three components are the basis of the assessment before logically formulate into another 3 components namely; Students, facilities/infrastructure and the role of the community. On the components of Students, the key word is the quality of learning which was formulated into 3 sub components namely: (1) characteristics of the Students, (2) background Students, and (3) the ability Students.

Components of the facilities and infrastructure, the key words are adequate sanitary facilities and infrastructure to support the quality of Islamic Senior High School. This component consists of 3 elements which include: (1) planning, (2) procurement, and (3) utilization. One last component in developing the quality of Islamic Senior High School is the role of the community. This component develops; the role of the community individually, the role of the community in groups, special role and the role of professional organizations.

\section{Product Test Results}

\section{Limited Test}

This test involved 90 subjects among others 15 staffs, 20 teachers, 15 parents and 40 students. Analysis of the test results aims to know the weaknesses of the instrument draft regarding all of the above mentioned aspects. The test I result is as follows:
Table 1. Limited Test

\begin{tabular}{|c|c|c|c|c|}
\hline \multirow{2}{*}{$\begin{array}{c}\text { The } \\
\text { Instrument }\end{array}$} & \multicolumn{2}{|c|}{$\begin{array}{l}\text { Total Item } \\
\text { correlation }\end{array}$} & \multirow{2}{*}{$\begin{array}{c}\text { The number } \\
\text { of Valid } \\
\text { Items }\end{array}$} & \multirow{2}{*}{$\begin{array}{l}\text { Alpha } \\
(\alpha)\end{array}$} \\
\hline & Min & Max & & \\
\hline Staffs & 0.309 & 0.802 & 67 & 0.970 \\
\hline Teachers & 0.305 & 0.819 & 152 & 0.984 \\
\hline Parents & 0.308 & 0.881 & 50 & 0.969 \\
\hline Students & 0.334 & 0.770 & 39 & 0.924 \\
\hline
\end{tabular}

Based on Table 1, it is known that the staffs' instrument has the number of valid items of 67 items, with minimum correlation value of 0.309 and the maximum correlation value of 0.802 . In addition the instrument of staffs has an Alpha value $(\alpha)$ of 0.970. Then the teachers' instrument has the number of valid items of 152 items, with the minimum correlation value of 0.305 and the maximum correlation value of 0.819 . The instrument of teachers has an Alpha value $(\alpha)$ of 0.987 . The parents' instrument has a number of valid items of 50 items, with the minimum correlation value of 0.308 and the maximum correlation value of 0.881 . The parents' instrument has the Alpha value $(\alpha)$ of 0.969. Students' instrument has the number of valid items of 39 items, with the minimum correlation value of 0.334 and the maximum correlation value of 0.770 . Students' instrument has the Alpha value $(\alpha)$ of 0.924 .

\section{Development Test}

This test involved 320 students, 70 teachers, 32 staffs and 30 parents. The results of the test II is as follows Table 2.

Table 2. Development Test

\begin{tabular}{|c|c|c|c|c|}
\hline \multirow{2}{*}{$\begin{array}{l}\text { The } \\
\text { Instrument }\end{array}$} & \multicolumn{2}{|c|}{$\begin{array}{l}\text { Total Item } \\
\text { correlation }\end{array}$} & \multirow{2}{*}{$\begin{array}{l}\text { The } \\
\text { Valid } \\
\text { Items }\end{array}$} & \multirow{2}{*}{$\begin{array}{c}\text { Alpha } \\
(\alpha)\end{array}$} \\
\hline & Min & $\operatorname{Max}$ & & \\
\hline Staffs & 0.303 & 0.780 & 55 & 0.954 \\
\hline Teachers & 0.311 & 0.671 & 124 & 0.974 \\
\hline Parents & 0.337 & 0.773 & 46 & 0.959 \\
\hline Students & 0.560 & 0.798 & 36 & 0.972 \\
\hline
\end{tabular}

Based on Table 2 it is known that the instrument of staffs has the number of valid items of 55 items, with the minimum correlation value of 0.303 and the maximum cor- 
relation value of 0.780 . Staffs' instrument has the Alpha value $(\alpha)$ of 0.954 . The teachers' instrument has a number of valid items of 132 items, with the minimum correlation value of 0.311 and the maximum of correlation value of 0.671 . Teachers' instrument has the Alpha value $(\alpha)$ of 0.974 . The parents' instrument has a number of valid items of 46 items, with the minimum correlation value of 0.337 and the maximum correlation value of 0.773 . Parents' instrument has the Alpha value $(\alpha)$ of 0.959 . Finally the students' instrument has a number of valid items of 36 items, with minimum correlation value of 0.560 and the maximum correlation value of 0.798 . Students' instrument has the Alpha value $(\alpha)$ of 0.972 .

Product Revision

Instrument Readability on the Role of Islamic Senior High School Head

The role of the Islamic Senior High School head consists of 6 dimensions, namely the dimensions of competency and personality, managerial competency, entrepreneurial competency, development of Islamic Senior High School competency, supervision competency and social competency. In the dimension of competency and personality, it consists of 3 indicators, dimensions of managerial competency consists of 6 indicators, entrepreneurship competency consists of 4 indicators, dimensions of development of Islamic Senior High School competency consists of 1 indicator, supervision competency consists of 2 indicators and social competency consists of 2 indicators. The assessment of readability instrument used the scale of 5 , with minimum score of 1 and maximum score of 5 .

\section{Islamic Senior High School Management Instru- ment Readability}

This variable consists of 6 assessment indicators, namely the dimension of the program planning and Islamic Senior High School, curriculum management, the management of the learning process, facilities and infrastructure, financial management focus- ed and the relationship with the community. In the dimensions of the program planning and Islamic Senior High School consists of 4 indicators, the dimensions of the management of the curriculum has 3 indicators, the dimensions of the management of the learning process has 3 indicators, dimensions of infrastructure has 3 indicators, dimensions of financial management has 5 indicators and finally the dimensions of the relationship with the community has 3 indicator.

\section{Educators and Staffs Test Instrument Readability}

The variables of the educators and staffs were examined by the questionnaires which consist of 3 appraisal dimensions, namely pedagogy competency dimension, and personality competency dimensions of social competency dimension. The dimension of the pedagogy competency consists of 3 indicators; personality competency dimension consists of 2 indicators and social competency dimension consists of 1 indicator.

\section{Students Instrument Readability}

Students' instrument consists of 3 dimensions to research, namely the dimension of the students' characteristics, the dimensions of the students' background and the dimensions of the students' ability. The dimension of the students' characteristic consists of 5 indicators, the dimension of the students' background consists of 2 indicators and the dimension of the students' ability consists of 4 indicators.

\section{Equipment and Infrastructure Instrument Read- ability}

The instrument of equipment and infrastructure consists of 3 dimensions, namely planning dimension, procurement dimension and utilization dimension. Planning dimension consists of 2 indicators, procurement dimension consists of 1 indicator and utilization dimension consists of 2 indicators.

\section{The Role of the Community Instrument Readability}

The role of the community instruments consists of 4 appraisal dimensions; there are the dimension of the role of the 
community -individuals, the role of the community in groups, special role and the role of professional organizations. The dimension of the role of the community individual consists of 2 indicators, the dimensions of the role of the community in groups consists of 4 indicators, the dimension of the special role consists of 2 indicators and dimension of the role of professional organizations consists of 2 indicators.

The Validity and Reliability

Based on the validity analysis using SPSS, it shows that all details of the number of good instruments such as instrument of the role of school principals, management Islamic Senior High School, testing educators and staffs, the role of the community, students facilities and infrastructures, have $r$ count (corrected item total correlation) which is greater than $r$ table as the minimum validity of the instrument point. This means that all of the instruments can be said as valid. A summary of the level of validity can be seen in the following Table 3 .

Based on the Table 3, it is known that the instrument the role of School Principals has a number of valid items of 17 items, with minimum score of 0.113 and maximum score of 0.787 . The instrument of the role of Islamic Senior High School has the Alpha value $(\alpha)$ of 0.908. Islamic Senior High School Management instrument has the number of valid items of 22 items, with minimum score of $0.179 \%$ in and maximum score of 0.594 Islamic Senior High School Management instrument has the Alpha value $(\alpha)$ of 0.862 .
Instrument of the Educators and Staffs has a number of valid items of 6 items, with minimum score of 0.587 and maximum score of 0.821 . The instrument of the Educators and Staffs has the Alpha value $(\alpha)$ of 0.899 . The Role of the community instruments has a number of valid items of 10 items, with minimum score of 0.519 and maximum score of 0.786 . The instrument Role of Society has the Alpha value $(\alpha)$ of 0.914 . Then the Instrument of Students has a number of valid items of 11 items, with minimum score of 0.446 and maximum score of 0.832 . The instrument of Students has the Alpha value ( $\alpha$ ) of 0.928 . The instrument of equipment and infrastructures have a number of valid items of 5 items, with minimum score of 0.604 and maximum score of 0.782 . The instrument of Students has the Alpha value $(\alpha)$ of 0.852 .

Estimation of the reliability of the instrument on the main field test used the SPSS program assistance, namely an analysis tool to determine proper instrument developed. Based on the results of the analysis using SPSS program assistance, it shows that Cronbach's Alpha for all the instruments $(\alpha)$ $\geq 0.7$ (above 0.7) which shows that the instrument can be said as reliable (Nunnally, 1978:230). Based on the analysis results using the SPSS program assistance, all the items of the instrument has an alpha coefficient $(\alpha)$ above 0.7 which shows that all of the instruments can be said as reliable. The summary of the calculation of the instrument reliability can be seen in the Table 4 .

Table 3. The Validity of the Islamic Senior High School quality

\begin{tabular}{lcccc}
\hline \multicolumn{1}{c}{ The Instrument } & \multicolumn{2}{c}{$\begin{array}{c}\text { Corrected item total } \\
\text { correlation }\end{array}$} & $\begin{array}{c}\text { Valid } \\
\text { Items }\end{array}$ & Alpha $(\alpha)$ \\
\cline { 2 - 3 } & Min & Max & & 0.908 \\
\hline The role of the head of the Islamic Senior High School & 0.113 & 0.787 & 17 & 0.862 \\
The management of Islamic Senior High School & 0.179 & 0.594 & 22 & 0.899 \\
Educators and Staffs & 0.587 & 0.821 & 6 & 0.914 \\
The role of the Community & 0.519 & 0.786 & 10 & 0.928 \\
Students & 0.446 & 0.832 & 11 & 0.852 \\
Equipment and Infrastructures & 0.604 & 0.782 & 5 & \\
\hline
\end{tabular}


Table 4. A Summary of the Level of Reliability of the Instrument

\begin{tabular}{lc}
\hline The instrument & $\begin{array}{c}\text { Cronbach's } \\
\text { Alpha }\end{array}$ \\
\hline $\begin{array}{l}\text { The role of the head of the Islamic } \\
\text { Senior High School }\end{array}$ & 0.908 \\
$\begin{array}{l}\text { The management of Islamic Senior } \\
\text { High School }\end{array}$ & 0.862 \\
Testing of the Educators and Staffs & 0.899 \\
Students & 0.928 \\
Equipment and Infrastructure & 0.852 \\
The role of the Community & 0.914 \\
\hline
\end{tabular}

The Study of the End Product

Variable of the Islamic Senior High School Role

The variable of Islamic Senior High School role was examined by the questionnaires consisting of the dimensions of competency and personality, managerial competency, entrepreneurial competency, development of Islamic Senior High School competency, supervision competency and social competency. In the competency dimension and personality there are 5 indicators, dimensions of managerial competency there are 12 Indicators, dimension of entrepreneurship competency there are 5 indicators, the dimensions of the development of Islamic Senior High School competency there are 5 indicators, the dimension of supervision competency there are 3 indicators and in the social competency there are 2 indicators.

Variable of Islamic Senior High School Management

Variable of Islamic Senior High School Management were examined by the questionnaires consisting of the dimensions of the program planning and Islamic Senior High School, the management of the curriculum, the management of the learning process, facilities and infrastructure, financial management focused, service students and the relationship with the community. The dimensions of the program planning and Islamic Senior High School there are 4 indicators, the dimensions of the management of the curriculum there are 6 indicators, the dimensions of the management of the learning process there are 5 indicators, dimensions of infrastructure and there are 5 indi- cators, financial management focused dimension there are 8 indicators, the dimension of the service of the students there are 5 indicators and in the dimension of the relationship with the community there are 3 indicator.

\section{The Variables of the Educators and Staffs}

The variables of the Educators and Staffs were examined using the questionnaires consisting of the dimensions of pedagogy competency, personality, social competence, professional competence, development for teacher competence, administration and the school guard. The dimension of the pedagogy competency there are 7 indicators, dimension of personality competence there are 5 indicators, dimensions of social competence there are 4 indicators, dimension of professional competence there are 5 indicators, dimension of development for teacher competence there are 4 indicators, dimension of administration there are 4 indicators and in the dimension of the school guard there are 2 indicators.

\section{$V$ ariable of Students}

Students' variable consists of the dimension of the Students' characteristics, Students' background and Students' ability. In the dimension of the Students' characteristics there are 5 indicators, the dimensions of the Students' background there are 2 indicators and in the dimension of Students' ability there are 4 indicators.

\section{Variable of Equipment and Infrastructure}

Equipment and Infrastructure variable consists of planning dimension, procurement and utilization. In planning dimension there are 2 items of question, procurement dimension there are 3 indicators and dimensions of the use of there are 3 indicators.

\section{Variable of the Community Role}

The Role of the community variables were examined by using the questionnaires consisting of the dimensions of the community role of individual, the community role in groups, special role and the role of professi- 
onal organizations. In the dimensions of the community role of individual there are 6 indicators, the dimensions of the community role in groups there are 6 indicators, di- mensions special role there are 2 indicators, and in the dimensions of the role of professional organizations there are 3 indicators.

Table 5. Islamic Senior High School Quality Testing Model

\begin{tabular}{|c|c|c|c|}
\hline The change & Factor Loading & Dimensions & Loading Factor \\
\hline \multirow{4}{*}{$\begin{array}{l}\text { The role of the head of the } \\
\text { Islamic Senior High School }\end{array}$} & \multirow{4}{*}{0,318} & The competency and Personality & 0.815 \\
\hline & & Managerial competence & 0.912 \\
\hline & & Entrepreneurial competencies & 0.680 \\
\hline & & Social competencies & 0.779 \\
\hline \multirow{3}{*}{$\begin{array}{l}\text { The management of } \\
\text { Islamic Senior High School }\end{array}$} & \multirow{3}{*}{0.447} & The management of the learning process & 0.805 \\
\hline & & Equipment and Infrastructure & 0.735 \\
\hline & & Financial Management & 0.748 \\
\hline \multirow{3}{*}{ Educators and Staffs } & \multirow{3}{*}{0.309} & Pedagogy Competency & 0.856 \\
\hline & & Personality Competency & 0.826 \\
\hline & & Social competencies & 0.705 \\
\hline \multirow{4}{*}{$\begin{array}{l}\text { The role of the } \\
\text { Community }\end{array}$} & \multirow{4}{*}{0.382} & The role of the community is an individual & 0.612 \\
\hline & & The role of the community groups & 0.871 \\
\hline & & Special role & 0.911 \\
\hline & & The role of professional organizations & 0.686 \\
\hline \multirow{3}{*}{ Students } & \multirow{3}{*}{0.342} & Characteristics of the Students & 0.750 \\
\hline & & The background of the Students & 0.724 \\
\hline & & The ability Students & 0.927 \\
\hline \multirow{3}{*}{$\begin{array}{l}\text { Equipment and } \\
\text { Infrastructure }\end{array}$} & \multirow{3}{*}{0.320} & Planning & 0.930 \\
\hline & & Manufacturing & 0.786 \\
\hline & & Utilization & 0.702 \\
\hline
\end{tabular}

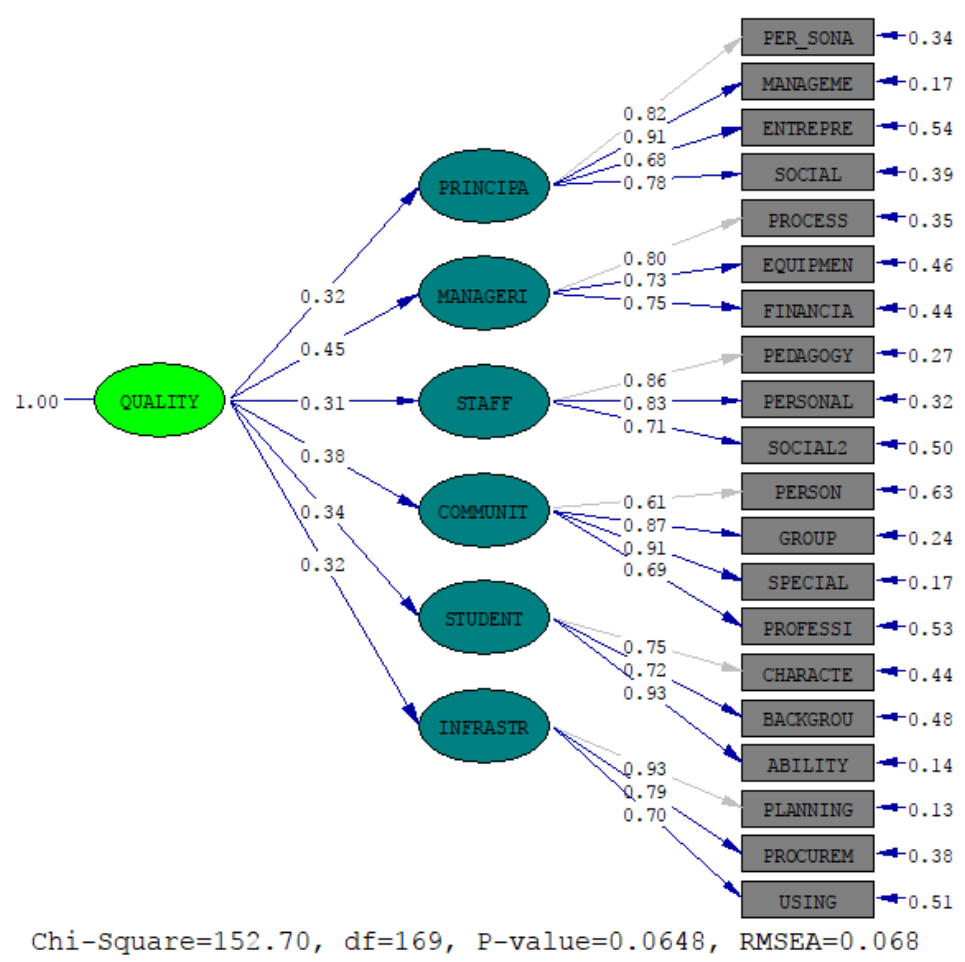

Figure 1. TheStandardized Solution of Model of Islamic Senior High School Quality 
The Results of Testing the Islamic Senior High School Quality Model Instrument

After the test was conducted for each constructs, then the test on the quality of Islamic Senior High School was compiled into a model. The model of the quality of Islamic Senior High School was composed of six constructs: The Role of School Principals, Islamic Senior High School Management, Educators and Staffs, Students, Facilities and Infrastructure and the Role of the Community.

Some findings obtained during research development of the model evaluation of the quality of Islamic Senior High School are supported by the information from interviews with some of the related parties. Informers have understood the quality of Islamic Senior High School that can be seen from the three elements namely the input, the process and the output: (a) The Input referred here is the educational background that students have acquired previously. Most of the students comes from Islamic Junior High School that have national examination total scores in average are 27 while students that come from general Junior Secondary School brought are only $25 \%$ of the total new students in one year. The other conditions that need to be considered is that the students can recite (read the Qur'an) or not. (B) The process is reviewed from the management side, services to students both in academic and nonacademic. (C) Output can be seen from the achievement of students, the performance of the school, the national examination result and the number of students that can be accepted in the Public Universities.

The condition of education in Islamic Senior High School in general according to informants should be increased toward the quality of Islamic Senior High School to be able to compete with other schools. Assessment of the informers on the role of Educators and Staffs in the effort to the quality of Islamic Senior High School revealed that the quality of Islamic Senior High School is currently still competitive with public schools; it is sometimes superi- or, sometimes under the public schools. This indicator can be seen from the results of the national examination achieved by the students and the number of students that can be accepted in the Public Universities. While in religious Universities, almost the majority of the graduates from Islamic Senior High School can be accepted.

The external and internal problems faced by the Islamic Senior High School are perceived to be complex. Some internal problems faced Islamic Senior High School today are: (a) the role of the school head in improving the quality that is less maximum, (b) Teachers in carrying out the tasks of teaching is less maximum, (c) learning tools and equipment are less adequate.

The role of the parents is: helping support the costs, supporting the school program, monitoring the development of student learning outcomes, and overseeing students' activities in study at home. The majority of the parents were very supportive to school programs such as cooperation between the school and the parents of the students in the new student enrolment, and the social activities in the community.

The main goals that underlie the parents to send their children to the Islamic Senior High School are: First, because of religious and moral education that are applied in the Islamic Senior High School, especially the female students that become the majority in the Islamic Senior High School compared to male students. Second, graduate students still play an important role in society even though they are not able to continue to higher education. The graduate students from Islamic Senior High School usually help to teach in TPA in reciting Qur'an or to be a Friday khotib at the mosque. The education cost in Islamic Senior High School is classified as relatively affordable by parents. The parents also can be assisted by BSM scholarship program from the Ministry of Religion for the poor students.

The condition of a few teachers is good but there is still much less good. This can be shown: (1) Teachers are still less 
discipline; (2) Teachers in delivering learning are difficult to understand; (3) Teachers less use variation learning methods; (4) Teachers in delivering learning are less systematic; (5) teachers do not give tasks when they are absent; (6) Teachers are less in adding knowledge, their teachings are text book oriented; 7) Teachers are less in giving services to students. Qualified teachers according to the informers are teachers, who can perform the tasks of teaching well, help students' difficulty in learning, give a good role model inside and outside the school and have sincerity in teaching.

The attention of the Islamic Senior High School head to extracurricular activities on the matter of fact is good but it needs to add some more choices for students to choose. The head of the Islamic Senior High School has not much attention to talented students that contributes to fewer added values to the quality of Islamic Senior High School. The characteristics of a quality Islamic Senior High School according to informers among others are: (a) having adequate facilities and infrastructure; (b) professional teachers; (c) giving good services; (d) good student achievement in learning results; (e) a comfortable and beautiful environment. When it is seen from the limitations time and the process of education in Islamic Senior High School, the informers feel satisfied.

\section{Research Limitations}

Although in general this model evaluation of the quality of Islamic Senior High School has several advantages, but in the process of research has some limitations as follows: (1) Research products in the form of model of the quality evaluation is limited to the level of Islamic Senior High School. The development of evaluation instruments need to do further research to level of Islamic Junior High School and Islamic elementary School; (2) Dissemination model of the evaluation of the quality of Islamic Senior High School have limited to the two Islamic Senior High School, development research should ideally be generalized if the research is wider and more heterogeneous in other places (Islamic Senior High School).

\section{Conclusion}

Based on the analysis of the data and discussion in previous chapters, this research and development result in form of a product of Quality Evaluation Instrument Model for Islamic Senior High School. The development of the instrument quality evaluation for Islamic Senior High School was done through three phases namely: (1) the pre-development, namely through examining the components of the quality of Islamic Senior High School; determining the specification of Islamic Senior High School quality evaluation; and determining strategy of developing Islamic Senior High School quality indicators, quality of instrument making strategy, strategy of making Islamic Senior High School quality evaluation guidelines. (2), the development phase in the form of drawing up a draft of the guidelines and evaluation instrument of Islamic Senior High School quality; investigations undertaken by the education experts and education practitioners appraisers for quality of school/Islamic Senior High School; trial evaluation instrument was validated in terms of clarity, while the quality indicator device and quality evaluation guidelines were validated in terms of simplicity and clarity of the language used. (3) dissemination and implementation stage of the developed instrument, dissemination was done to socialize the developed Islamic Senior High School quality evaluation to some related parties.

The evaluation on the quality of Islamic Senior High School was done on the six areas, namely: (1) the role of school principals, (2) management of Islamic Senior High School, (3) professionalism of educators and staffs, (4) students, (5), the availability of facilities and infrastructure, and (6) the role of the community. On the trial implementation of the model of Islamic Senior High School quality evaluation instrument that was done to the teachers, educators, students and parents showed 
that the evaluation instruments have a quite good level of validation with the total item correlation score ranging from 0.305 to 0.881 . Based on the analysis of the known feasibility, the instrument readability of the role of the Islamic Senior High School is 3.89; Islamic Senior High School management instrument readability is 4.09; educator and staffs instruments readability is 3.85 ; Students instrument readability is 4.23 ; equipment and infrastructures instrument readability is 4.07; and the role of the community instrument readability is 4.09 .

The reliability of the instrument of Islamic Senior High School Quality Evaluation Model has high values with Cronbach Alpha values ranged between 0.852 and 0.928 . The validity for all constructs in Islamic Senior High School quality evaluation model is also quite good with the factor loading value of more than 0.30 . Testing of the structural Islamic Senior High School quality evaluation model is also declared as fit with the RMSEA value of less than 0.08 .

Coherency level of the instrument of Islamic Senior High School Quality Evaluation model when it is used to assess the quality of Islamic Senior High School is in accordance with the design. Instrument of Islamic Senior High School Quality Evaluation model can provide good information to support each other and complement between descriptive data and qualitative data including between the sources data obtained.

The advantages of Islamic Senior High School Quality Evaluation model instrument in the implementation process to measure the quality of Islamic Senior High School are as follows; (a) it is comprehensive, because the components and quality of the quality indicator represents almost all the activities of educational implementation, (b) it is holistic approach, because it can uncover the real facts of what is happening in schools, (c) it is easy, (d) it does not depend on the specific lessons conducted by educators. (e) it can be used to map the various aspects of the education in Islamic Senior High School that need to be repaired, (f) it is open to further development, (g) instrument evaluation of the quality of Islamic Senior High School can be used as a school self-evaluation, (h) it can be used effectively at schools without interrupting the learning process, (i) it supports school accreditation and quality guarantee, and (j) it is independent because involving the school committee.

Based on the research findings, it can recommend some important things namely, Islamic Senior High School quality evaluation model can be used by the management and the Head of the Islamic Senior High School to improve the quality by doing the construction based on the core components in the model evaluation or in the decision making related to the implementation of the Islamic Senior High School program. It needs for further development of the Islamic School quality evaluation model to the level of Islamic Junior High School and Islamic Elementary School.

\section{References}

Ahid, N. (2009). Its problem madrasah aliyab $(M A)$ in Indonesia. Kediri: STAIN Release.

Ariani, D. W. (2004). Quality management: approach qualitative side. Jakarta: Ghalia Indonesia.

Aspin, N. D., Chapman. D. J., \& Wilkinson, H. V. (1994). Quality schooling: $A$ pragmatic approach tackles the current problems, topics and issues. London: Cassell.

Borg, W. R., \& Gall, M. D. (1983). Educational research: An introduction (4th ed.). New York: Longman Publishing.

Cheng, Y. C., \& Ming, W. T. (1997). Multiple models of quality in education. Quality Assurance in Education. Retrieved March 16, 2012, from http://www.proquest.com/pqdweb.ht $\mathrm{ml}$

Daulay, H. P. (2007). Historisitas dan eksistensi pesantren, sekolah dan madrasah. Yogyakarta: PT Tiara Wacana. 
Edmonds, R. (1979). Effective Schools for the Urban Poor. Educational Leadership, $37(1)$.

Fadjar, M. (1998). The madrasah and the challenges of modernity. Bandung: Mizan

Glatthorn, A. A., Jones, B. K., \& Bullock, A. A. (2006). Developing debts qualified class teachers. California: Corwin Press.

Jonah, M. (1996). The history of Islamic education in Indonesia. Jakarta: Hidakarya Agung.

Komariah, A. (2005). The influence of the visionary leadership and culture of the schools to the effectiveness of the school in the era of decentralization at the SMAN in the environment of the Education City of West Java Province. Dissertation. The University of education in Indonesia. Retrieved February 12, 2012, from http://www.proquest.com/pqdweb.ht $\mathrm{ml}$.

Kyle, U. S. (1985). Continuous auctions and inside intrading. Econometrica, 53(6).

Mahdi, M. (2016). Development strategy of madrasah education in Indonesia. Edueksos: Journal of Social Education \& Economy, 4(2).

Maksum, (1999). The Madrasah, history and its development. Jakarta: Logos

Menteri Pendidikan Nasional. (2002). Ringkesan kegiatan belajar mengajar. Jakarta: Depdiknas.

Menteri Pendidikan Nasional. Peraturan pemerintah republik indonesia nomor 19 tahun 2005 tentang standar nasional pendidikan (2005).

Menteri Pendidikan Nasional. Peraturan Menteri Pendidikan Nasional Nomor 16 Tahun 2007 tentang Standar Kualifikasi Akademik dan Kompetensi Guru (2007).

Nasution, M. N. (2001). Integrated quality management (total quality management). Jakarta: Ghalia Indonesia.

Nizar, S. (2011). The bistory of Islamic education to trace the bistory of education in the era of Rasulallab to Indonesia. Jakarta: Kencana.

Padmo, D. (2003). The factors of designbased Mathematics and Science learning culture. In P. Padmo (Ed.), Learning Technology. Jakarta: UT, Pustekom, IPTPI.

Rahman, K. A. (2012). The improvement of the quality of Madrasah through strengthened community participation. The Journal of Islamic education, I(2).

Reigeluth, C. M. (1983). Instructional design: What is it and why is it? In C. M. Reigeluth (Ed.), Instructional design theories and models: An Overview of their current status. Hillsdale, N. J.: Lawrence Erbaum Associates.

Sallis, E. (1993). Total quality management in education. London: Kogan Page, Philadelphia

Sallis, E. (2002). Total quality management in education (3rd ed.). London: Kogan Page, Ltd.

Shaleh. A. R. (2004 ). The Madrasab and children education vision, mission and action. Jakarta: PT. King Grafindo Persada.

Subijanto, \& Wiratno, S. (2012). Analysis of the performance of the National Accreditation School/Madrasah. The Journal of Education and Culture, 18(3).

Suhardjono, (1990). The influence of cognitive style and the design of teaching by component display theory of learning acquisition and retention attitudes. Dissertation unpublished. Malang: FPS of IKIP Malang

Sumayang, L. (2003) The basics of production management and operations. Jakarta: PT. Salemba Four Patria.

Taylor, M. J., West, R. P., \& Smith, T. G. (2006). The indicators of school quality (ISQ) survey manual. Logan, UT: Utah State University. Retrieved from www.csf.usu.edu

Tilaar, H. A. R. (1999). Beberapa agenda reformasi pendidikan nasioanl dalam 
perspektif abad 21. Jakarta: Indonesia Tera.

Tilaar, H. A. R. (2000). Paradigma baru pendidikan nasional. Jakarta: Rineka Cipta

Tjandrasasmita, U. (1984). Sejarah nasional Indonesia III. Jakarta: Balai Pustaka

Umaedi, (1999). The improvement of the quality of school-based management. A new approach in the management of the school for the improvement of the quality of the. Jakarta: Depdikbud
Widdah, M. E. (2013). Pengelolaan madrasah (studi kualitatif tentang manajemen strategi Madrasah Aliyah Negeri di Kota Jambi). Al-Ulum, 2.

Widdah, M. E., Suryana, A., \& Musyaddad, K. (2012). Kepemimpinan Berbasis Nilai dan Pengembangan Mutu Madrasah. Bandung:Alfabeta

Zeithaml, V. A., \& Bitner, M.J. (2002). Service marketing: Integrating customer focus accross the firm $3^{\text {rd }}$ Edition. The Mc.Graw-Hill Companies 